\title{
Analysis of the Difficulties and Countermeasures of Cross-border E-commerce Logistics in Fujian
}

\author{
Bo Wang \\ Economic Trade Department of Fuzhou University of \\ International Studies and Trade, Changle, China
}

\author{
Juan Qiu \\ Economics and Management Department of Fujian \\ Vocational College of Agriculture, Fuzhou, China
}

\author{
Jiaying Liao \\ International Business Department of Concord University College Fujian Normal University, Fuzhou, China
}

\begin{abstract}
E-commerce and logistics are interdependent and coexisting, and the cross-border e-commerce is inseparable from cross-border logistics. With continuous development of crossborder e-commerce in Fujian, cross-border logistics has encountered unprecedented difficulties. This paper analyzes the difficulties of cross-border e-commerce logistics and puts forward suggestions such as building overseas warehouses and strengthening logistics information construction based on an analysis on the status quo of cross-border e-commerce and logistics in Fujian.
\end{abstract}

Keywords-Cross-border e-commerce; Logistics; Overseas warehouse; Fujian

\section{INTRODUCTION}

In the last two or three years, the volume of e-commerce transaction in Fujian has been increasing, especially in relatively developed coastal areas such as Fuzhou, Xiamen and Quanzhou. As such increase, cross-border e-commerce in Fujian is also developing continuously. According to the data of the Fujian Provincial Bureau of Statistics, the total crossborder transaction volume of our province was about RMB 1 trillion in 2015, of which cross-border e-commerce transaction amounted to about RMB 62 billion, accounting for about $6.2 \%$ of total import and export volume in Fujian. However, while Fujian's cross-border e-commerce is booming, Fujian's crossborder logistics is left far behind it. The development of crossborder logistics in Fujian is constrained by six aspects: high logistics cost, long transportation period, high goods return and exchange rate, high product loss rate, difficult information tracking and the gap between supply and demand of thirdparty logistics. Therefore, all the cross-border e-commerce and logistics companies should energetically develop overseas warehouses to solve the issues in cross-border logistics in Fujian; The provincial government should provide some relevant preferential policies to the cross-border e-commerce and third-party logistics companies to solve the development of cross-border logistics in Fujian.

\section{ANALYSIS ON THE STATUS QUO OF FUJIAN'S CROSS- BORDER E-COMMERCE LOGISTICS}

A. The status quo of cross-border e-commerce

On October 16, 2015, the Fujian Cross-border ECommerce Association was formally established. Its establishment facilitates the convenience of engaging in crossborder e-commerce activities among members and the resources and experience share. With the mutual help of members, more cross-border e-commerce business can be realized. The Association deepens the cooperation with largescale e-commerce platforms such as Alibaba, Amazon and eBay, and promotes the cooperation between platforms such as Tmall International, Alipay and Rookie Logistics and Pingtan KJT, etc. to ensure more convenient performance of cross-border e-commerce activities in our province. At present the Fujian provincial government supports a lot of local companies to participate in the import pilot, and encourages each company to develop more bonded import and direct shopping import businesses, to increase cross-border ecommerce import transaction volume. Fujian's cross-border ecommerce companies

In the last ten months, the volume of cross-border ecommerce transaction has grown tremendously in Fujian. We can know from the Inspection and Quarantine Bureau of Fujian, from January to October, 2016, there were 242 batches of cross-border e-commerce imported goods with a value of RMB 132 million, and 222,700 orders of exported goods with a value of RMB 88.3447 million in Fujian, and the import and export respectively grew by $216 \%$ and $141 \%$ compared with the corresponding period of last year. In order to energetically develop cross-border e-commerce, the Fujian government has provided a series of preferential policies. For example, a special distribution center for cross-border e-commerce was set up in the special customs supervision area to ensure smoother operation of cross-border e-commerce activities; $30 \%$ subsidies, not more than RMB 1 million, are granted to cross-border e-commerce companies with a site area of more than 3,000 square meters; What's more, subsidies not more than RMB 1 million are granted to cross-border e-commerce 
and logistics companies of Fujian that have passed through the Fujian ports. Our province has completed the construction of the electronic port platforms, and most of the public service platforms of cross-border e-commerce have been available, allowing the integrated inquiry on customs, commodity inspection, foreign exchange, tariff and other regulatory platforms. The provincial government is improving the public service platforms of cross-border e-commerce in Pingtan, Fuzhou and Xiamen, enabling the real-time inquiry for crossborder e-commerce companies in Fujian.

\section{B. The conditions of cross-border e-commerce logistics}

The cross-border e-commerce logistics comprises of many steps. Here, the cross-border logistics of agricultural products in Fujian is used to mainly explain the process of the crossborder e-commerce logistics. As an important part of the cross-border e-commerce logistics of Fujian, the cross-border logistics of agricultural products plays an important role in cross-border logistics in Fujian. The cross-border logistics process of agricultural products includes not only the circulation of goods from producers to consumers, but also the cross-border return and exchange process of agricultural products [1] constituting a complete cross-border e-commerce logistics of agricultural products, with the improvement of cross-border e-commerce after-sales service system. The flow chart is shown as follows:

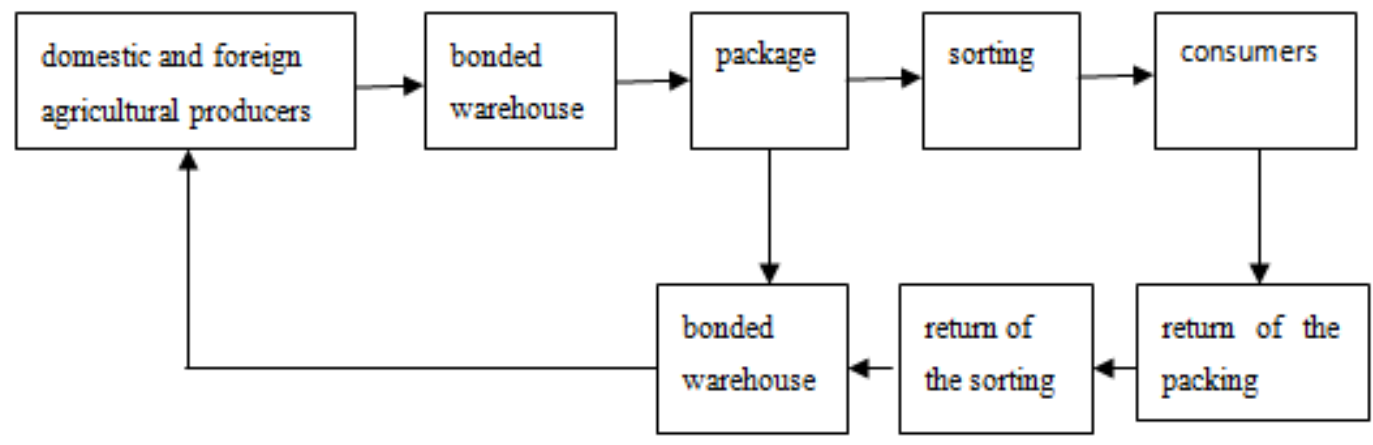

Fig. 1 A brief diagram of cross-border logistics of agricultural products

As shown in Figure 1, we can know that a complete crossborder logistics of agricultural products comprises of domestic and foreign producers of agricultural products, bonded warehouses, packaging, sorting, consumers, return packaging and return sorting processes.

In recent years, Fujian cross-border e-commerce has developed rapidly from nothing. In 2012, Fuzhou City and Xiamen City were listed as the first batch of e-commerce demonstration cities in China. In 2014, Quanzhou City and Putian City were listed as the second batch of e-commerce demonstration cities in China. And in 2015 Fuzhou City and Pingtan City were approved as pilot cities for cross-border ecommerce bonded import. In the same year, the Fujian Crossborder E-Commerce Association was established. Although the cross-border e-commerce of Fujian has developed rapidly, the cross-border logistics system has not been perfected, and has not been able to keep up with the goods transportation in cross-border e-commerce activities. According to the 2015 Cross-border E-Commerce Trend Report released by Amazon China, in 2015, the number of cross-border e-commerce sellers in Fujian was next only to in Guangdong, ranking second in China. The volume of cross-border e-commerce transaction in the province was close to RMB 200 billion with a year-on-year increase of $42 \%$, accounting for about a quarter of the province's total import and export volume. Also, there were more than 10,000 companies engaged in cross-border ecommerce in the province. At present, the cross-border logistics in Fujian mainly comprises of five modes: international postal small parcel, international express, international special circuit logistics, cross-border third-party logistics and overseas warehouse.
Along with the development of cross-border e-commerce of Fujian, the cross-border logistics has also evolved from the original single postal parcel to the diversified format of "postal parcel based and other modes coexisting" in Fujian. More and more express companies and logistics companies in the province are launching international routes to meet the needs of cross-border e-commerce. For example, SF Express has launched the International Biaokuai (international) service product. In order to better meet the needs of provincial crossborder e-commerce, and some large-scale logistics companies in the province have also begun to involve in the construction of overseas warehouses.

\section{The status quo of logistics companies of cross-border e- commerce}

Fujian owns currently SF Express, STO Express, Post EMS, ZJS Express, YTO Express, Yunda Express, TTK Express, ZTO Express, Best Express, Guotong Express and other express companies, of which, the express companies involved in cross-border e-commerce logistics include only SF Express, Post EMS, STO Express, ZJS Express, YTO Express, ZTO Express and Yunda Express. In order to seize the opportunity of cross-border logistics, SF Express has launched the SF Biaokuai (international) product, including Australia, Vietnam, Thailand, the United States, Japan, Malaysia, South Korea, Singapore, Russia, Indonesia, India, Cambodia, Canada, Mexico and Myanmar. In order to develop crossborder logistics, EMS has launched international logistics routes, including Australia, Hong Kong, Japan, South Korea, the United States, the United Kingdom, Spain, France, etc. STO Express has also launched international logistics routes 
to adapt to the development of cross-border logistics, including Hong Kong, Taiwan, South Korea, Japan, Southeast Asia, Europe, Middle East, North America and other countries or regions. ZJS Express has launched international routes to adapt to the development of cross-border logistics, including the United States, Japan, Russia, Taiwan, Hong Kong, Europe, Middle East and other countries or regions. Also, YTO Express has launched some international logistics routes to seize the opportunity for cross-border e-commerce logistics, including the United States, Europe, Australia, Japan, South Korea, Southeast Asia, Middle East and other countries or regions. The development of cross-border logistics of ZTO Express is relatively slow, currently only including Russia and some European countries. And the development of crossborder logistics of Yunda Express is also relatively slow, currently only including Hong Kong, Macao and Taiwan.

\section{THE DIFFICULTIES OF CROSS-BORDER E-COMMERCE LOGISTICS IN FUJIAN}

\section{A. High logistics cost}

For generally transacted goods, the logistics cost will account for $35 \%$ to $45 \%$ of the total cost. Then we can see that the logistics cost of cross-border e-commerce is more expensive, because cross-border e-commerce comprises of cross-border trade, cross-border logistics and logistics distribution, among which the cross-border logistics is the most troublesome. Cross-border logistics involves domestic transportation, domestic logistics, domestic customs, international transportation, foreign logistics, foreign customs, etc, among which, customs and commodity inspection, risk and operation difficulty are more uncertain, which increases the cost of cross-border logistics [2]. Cross-border logistics, including sea, land and air combination, involves more logistics processes, which greatly increases logistics cost. Often, an additional mode of transportation will bring the freight increase, while freight increase will bring greater difficulties to cross-border e-commerce logistics. At present, for the most expensive air transportation, there are not many airports in Fujian, the route density is not enough, segmental logistics still dominants the industry generally, and pointbased logistics has not yet been realized, all of which have led to further increase in logistics price.

Next, let's take SF Express as an example to briefly explain the logistics cost incurred by cross-border e-commerce. From Table 1, we can know that the freight from the United States, Japan or Singapore to Fuzhou is several times higher than that from Shanghai to Fuzhou. So the cross-border e-commerce logistics cost is much higher than the domestic logistics cost, and logistics cost accounts for a large part of the total cost of goods. We can conclude that the high logistics cost incurred by cross-border e-commerce has seriously affected the development of cross-border e-commerce logistics in Fujian.

TABLE I. SF EXPRESS FREIGHT LIST

UNIT: RMB

\begin{tabular}{|c|c|c|c|c|c|c|}
\hline & $1 \mathrm{~kg}$ & $5 \mathrm{~kg}$ & $10 \mathrm{~kg}$ & $15 \mathrm{~kg}$ & $20 \mathrm{~kg}$ \\
\hline $\begin{array}{c}\text { United States - } \\
\text { Fuzhou }\end{array}$ & 206 & 359 & 485 & 594 & 703 \\
\hline Japan - Fuzhou & 135 & 326 & 582 & 838 & 1025 \\
\hline $\begin{array}{c}\text { Singapore - } \\
\text { Fuzhou }\end{array}$ & 150 & 339 & 533 & 678 & 824 \\
\hline $\begin{array}{c}\text { Shanghai - } \\
\text { Fuzhou }\end{array}$ & 22 & 62 & 112 & 162 & 212 \\
\hline
\end{tabular}

a. Source: SF EXPRESS official website

\section{B. Long transportation period}

The characteristics of cross-border e-commerce itself make logistics go through more links, besides customs and commodity inspection take a long time, resulting in Fujian's cross-border e-commerce logistics period is much longer than domestic e-commerce logistics. In terms of cross-border logistics, the time issue of transportation and distribution is prominent. Some goods need to be transported to our province from the United States, Japan, Singapore, South Korea, Australia, the United Kingdom, etc., with a remote distance. If goods are transported by sea, it will take a month or two months to arrive at the distant country, and the climate at sea changes eternally, it is possible not to sail at any time, seriously affecting the time of goods transportation. Especially in the shopping season such as double 11, the domestic logistics is slower than usually, and it is nothing more than aggravating cross-border logistics difficulties at this time.
With the rapid development of cross-border e-commerce, more and more people like Haitao, and more people prefer overseas shopping, but the long transportation period has always been a big problem.

Next, let's take SF Express logistics as an example to briefly explain the logistics transportation time required for the cross-border e-commerce. From Table 2, we can clearly see that it takes much more time for cross-border e-commerce logistics than domestic logistics, which has greatly affected the development of cross-border e-commerce logistics in our province. The increase in transportation time hinders the possibility of more cross-border e-commerce, and also hinders the normal development of cross-border logistics. From the case of this paragraph, we can conclude that the long transportation period has seriously affected the development of cross-border e-commerce logistics in our province. 
TABLE II. SF EXPRESS TRANSPORTATION TIME UNIT: DAY

\begin{tabular}{|c|c|c|c|c|c|}
\hline & $\begin{array}{c}\text { United States } \\
\text { - Fuzhou }\end{array}$ & $\begin{array}{c}\text { Korea - } \\
\text { Fuzhou }\end{array}$ & Japan - Fuzhou & $\begin{array}{c}\text { Singapore - } \\
\text { Fuzhou }\end{array}$ & $\begin{array}{c}\text { Shanghai - } \\
\text { Fuzhou }\end{array}$ \\
\hline $\begin{array}{c}\text { Transportati } \\
\text { on Time }\end{array}$ & $12-15$ & $6-8$ & $8-9$ & $4-6$ & $1-2$ \\
\hline
\end{tabular}

b. Source: SF EXPRESS official website

\section{High goods return and exchange rate}

In the cross-border e-commerce logistics activities, there will always be a problem of goods return and exchange which is often impossible to solve. The characteristics of crossborder e-commerce itself lead to a series of problems, such as high goods return and exchange rate, loss of goods and errors in delivery addresses, all of which have led to the goods return and exchange logistics.

Suppose one of our province's consumers buys an Australian product, but it is found that the product is seriously damaged after bought home, he/she requires a return to the Australian manufacturer. It will take a lot of time to return the product to Australia from our province, and during the period, cross-border e-commerce logistics and customs clearance are needed, so that the there is no smooth channel for the goods back to the consumer. What's more, there are some cultural characteristics of "goods of return and exchange without reasons" in Europe and the United States, so that the goods return and exchange rate for cross-border e-commerce continues to rise in our province. From the above, we can conclude that goods return and exchange issue is also the major difficulty for cross-border e-commerce logistics.

\section{High product loss}

Cross-border e-commerce in Fujian is subject to domestic transportation, international transportation and foreign transportation, but we are not sure about the international transportation phase and the foreign transportation phase. During the international transportation process, various damages to the goods can be caused due to the environmental influence; During the foreign transportation process, damages to the goods can also be caused often because of beyond our country's logistics distribution. The high product loss rate has reduced more cross-border e-commerce business, which has seriously affected the development of cross-border business logistics in our province.

Taking the agricultural products as an example, due to the specific characteristics of agricultural products, there exist strict temperature requirements during transportation and storage. In order to ensure the quality and safety of agricultural products, a whole-process temperature control is needed during the transportation and storage of agricultural products. Because cross-border logistics of agricultural products is a circulation process from farmers or processing companies directly to consumers through storage and crossborder transportation, so the requirements to logistics are relatively high. There exist many circulation links, and the temperature control technology conditions are different in different countries and regions, which make it impossible to realize the whole-process temperature control in real sense for cross-border logistics of agricultural products. In addition, because adopting the whole-process temperature control will bring an increase of logistics cost, some companies only use ordinary vehicles for transportation, which makes the loss rate of agricultural products rise during transportation and storage. It is understood that the loss of agricultural products such as fruits and vegetables is as high as 30\% 50\% in the links of picking, transportation, storage, etc. in our province, while in developed countries, the loss is only $5 \%$.

\section{E. Difficult information tracking}

In the usual e-commerce logistics system in our province, major logistics companies basically have the function of tracking goods information throughout the whole process, but the tracking of goods logistics information for cross-border ecommerce is generally not realized. Since cross-border ecommerce logistics includes both provincial logistics and international logistics, there is a relatively complete logistics tracking system in our province, and information tracking can be basically achieved; However, it is difficult for us to track information throughout the whole process after the goods leave our country, because the informatization level of logistics information systems in many foreign countries is not high. For example, we open Haitao's page from Taobao and buy a pair of Vietnamese Nike sneakers, it usually takes about ten days to see the updated logistics information, because the logistics information system in Vietnam is not perfect, we can hardly see the specific logistics information. Only after the goods arrive at the customs of our province, we can see the updated logistics information. It can be seen that cross-border information is difficult to track, which has seriously affected the development of cross-border e-commerce logistics in our province.

\section{F. The gap between supply and demand of third-party logistics}

The third-party logistics system comprises of storage, package, transportation, sorting, distribution, etc. Due to the relatively short development time of third-party logistics in Fujian, its foundation is still weak, the infrastructure is not perfect, the logistics system is still not perfect, and the logistics functions such as storage, transportation and distribution are in poor coordination [3]. The construction of third-party logistics system is unqualified, the transportation mode of third-party logistics is relatively simple, the road, railway, sea, air transportation, etc. are separate from each other, with poor coordinating and supporting operation capabilities, and the perfect multimodal transportation system 
of third-party logistics has not been completed, resulting in the current less efficient logistics system.

In the past two or three years, Fujian's cross-border ecommerce has developed rapidly, leading to an increase in demand for third-party logistics. The development of thirdparty logistics is relatively late in Fujian, which makes the development level of third-party logistics companies in our province far lower than other coastal provinces in China, resulting in the demand far more than supply for the thirdparty logistics. Moreover, because the Fujian administration for industry and commerce regards logistics as the third source of profit, only seeing the current interests and not looking forward to further goals, the third-party logistics companies can not develop comprehensively, which leads to weak service capabilities of third-party logistics. Most of the third-party logistics companies dare to develop in the province but not its outside, because they lack funds and experience. The supply and demand of third-party logistics disconnect, which causes that our province's cross-border logistics system can not be more perfect, seriously affecting the development of crossborder e-commerce logistics in our province.

\section{COUNTERMEASURES AND SUGGESTIONS}

\section{A. Reducing logistics cost}

Cross-border e-commerce logistics includes various combinations of land, sea and air transportation, involving more logistics processes, which greatly increases logistics cost Therefore, the government should provide various preferential policies to maritime goods companies, various land transport companies and airline companies to reduce their costs of cross-border e-commerce logistics. In terms of customs clearance and commodity inspection, risks and operations are more difficult, which also greatly increases the cost of crossborder logistics. Therefore, the government should shorten the time for customs clearance and commodity inspection to ensure the circulation of cross-border e-commerce. Thus the cost of cross-border logistics can be reduced.

\section{B. Speeding up transportation}

The characteristics of cross-border e-commerce trade itself make the logistics process main, and the long time of customs clearance and commodity inspection and the time conflict between transportation and distribution make the cross-border logistics transportation period long [4]. Therefore, first of all, each logistics company should speed up own logistics transportation and distribution, and then the government should give policy encouragement and cooperation in import and export cross-border e-commerce logistics, for example, the government can set up a special service window for it to shorten customs clearance and commodity inspection. Thus the logistics transportation period can be shorten rapidly.

\section{Vigorously developing overseas warehouses}

Overseas warehouses can effectively reduce logistics cost, shorten transportation period and facilitate goods return and exchange. Therefore, governments, large-scale logistics companies and cross-border e-commerce companies should work together to build overseas warehouses in large trading countries with developed cross-border e-commerce and policies permitting the building, in order to ensure the realization of goods return and exchange for cross-border ecommerce logistics. Besides it is necessary to further improve customs clearance efficiency, shorten marketing links, reduce logistics cost, improve distribution efficiency, help companies better integrate into overseas circulation systems, etc., so as to accelerate the construction of cross-border e-commerce overseas warehouses.

\section{Strengthening goods protection}

In cross-border e-commerce logistics activities, product damage is inevitable, especially for fragile and perishable products that are susceptible to external influences. Therefore, for some fragile items, we should give special packaging; for perishable items, we should adopt special packaging and transportation methods; for items that are easy to be squeezed, we should classify, accurately place them, etc. In short, for items that are traded across borders, we need to strengthen protection to ensure that its damage rate can be reduced.

\section{E. Strengthening information construction}

It is necessary to strengthen the informatization construction of cross-border e-commerce logistics companies for improving the development of cross-border logistics. On the one hand, cross-border e-commerce logistics companies should establish a logistics tracking information system or related public platform matched to the country's information system according to the informationization level and characteristics of different countries. On the other hand, crossborder e-commerce companies and related logistics service providers should accelerate the standardization project of cross-border logistics in storing, transporting, loading, unloading, handling and packaging combining with national industry associations, which can support the establishment of cross-border information tracking platform. In addition, advanced technologies such as big data, "Internet + ", and smart logistics should be used, to achieve a coordination among cross-border e-commerce companies, logistics companies, customs and other parties at home and abroad, jointly build a whole-process monitoring and tacking and seamless docking information platform, achieve in-time and accurate positioning of goods, and provide security for consumers [5]. 


\section{F. Supporting the development of third party logistics}

The third-party logistics companies in our province should learn from excellent third-party logistics companies in other provinces to develop better, courageously cooperate with the cross-border e-commerce companies, and constantly improve the third-party logistics system. The government will provide relevant preferential policies to third-party logistics companies, improve the informationization level and service capabilities of third-party logistics, and balance the supply and demand of third-party logistics to meet the development of cross-border e-commerce logistics in our province.

\section{CONCLUSION}

The cross-border e-commerce is developing rapidly in Fujian, but its further development is restricted with the bottleneck of logistics. The special geographical condition of "Eight parts mountain, one part water, and one part farmland" in Fujian makes the logistics issues difficult to solve. We need to comprehensively and energetically strengthen the hardware construction of three-dimensional sea, land and air network, meanwhile, strengthen the software construction such as logistics informationization, reduce the loss rate of goods, shorten customs clearance, develop overseas warehouses, etc.

\section{REFERENCES}

[1] Guoshan Han Research on the Construction of Cross-border Ecommerce Logistics System of Henan Agricultural Products under the "Belt and Road" [D]. Zhengzhou: Henan University of Technology, 2016.

[2] Xiaheng Zhang, Tianshan Ma. Analysis on Difficulties and Countermeasures about China's Cross-border E-commerce Logistics [J]. Contemporary Economic Management, 2015, 37 (5): 51-54.

[3] Chen Wang. Research on China's Cross-border E-commerce Logistics Model under the "Belt and Road" Strategy [J]. Logistics Technology, 2017 (6): 33-36.

[4] Minghui Ouyang. Research on the Status Quo and Countermeasures about Cross-border E-commerce Logistics in China [J]. Logistics Engineering and Management, 2016, 38 (6): 104-106.

[5] Xiaojun Liu, Bin Zhang. China's Collaborative Development with the Countries along the "Belt and Road" in Cross-border E-commerce Logistics [J]. China Business and Market, 2016 (5): 115-120. 